\title{
Effect of Normal Range Serum Thyrotrophin Levels on Bone Mineral Density of post-menopausal women and older men
}

Jingfang Liu ( $\sim$ ljf824168@126.com)

the first hospital of lanzhou university https://orcid.org/0000-0003-1908-4454

Liping Qin

the first hospital of lanzhou university

Songbo Fu

Wuhan University Renmin Hospital

Xulei Tang

the first hospital of lanzhou university

Lihua Ma

the first hospital of lanzhou university

Binli Wang

the first hospital of lanzhou university

Yujuan Li

the first hospital of lanzhou university

Dan Wu

the first hospital of lanzhou university

Weiming Sun

the first hospital of lanzhou university

Ying Niu

the first hospital of lanzhou university

Gaojing Jlng

the first hospital of lanzhou university

\section{Research article}

Keywords: Thyrotrophin, Bone mineral density, Osteoporosis, Older men, Post-menopausal women

Posted Date: December 3rd, 2019

DOI: https://doi.org/10.21203/rs.2.11894/v2 
License: (c) (i) This work is licensed under a Creative Commons Attribution 4.0 International License. Read Full License 
The authors have withdrawn this preprint from Research Square 